\title{
Problemetan Oinarritutako Ikaskuntza (POI) unibertsitatean: bere aplikazioa ikerketa metodologiako irakasgai batean
}

Jone Aliri Lazcano

Hezkuntzako Ikerkuntza eta Diagnosi Metodoak Hezkuntza, Filosofia eta Antropologia Fakultatea Euskal Herriko Unibertsitatea (UPV/EHU)

Nerea Lertxundi Iribar Arantxa Gorostiaga Manterola Laura Vozmediano Sanz Ana Isabel Vergara Iraeta

Gizarte Psikologia eta Portaera Zientzien Metodologia

Psikologia Fakultatea Euskal Herriko Unibertsitatea (UPV/EHU)

DOI: $10.1387 /$ tantak.16342

\section{SARRERA}

Hainbat urte pasa dira Goi-mailako Hezkuntzaren Europako Esparrua (GHEE) sortu zenetik, eta orduz geroztik unibertsitateak oro har eredu berri horretara egokituz joan dira (Campos eta Juaristi, 2008). Esparru berri honek hainbat helburu bultzatu ditu. Agian ezagunenetarikoa izan da herrialde batean lortutako titulazio batek, beste herrialde batean ere balio izan dezan, Europa mailan elkarrekin konpara daitekeen titulazio eta kalifikazio sistema bat sortzea, baina hau ez da helburu bakarra. Esparru berri honetara egokitzeak oinarrian erronka garrantzitsu bat planteatzen du, ikasteko sistema aldatzea, alegia. Horrek, hezkuntza praktikoagoa, aktiboagoa eskatzen du, eta ikasketa unibertsitarioarekiko jarrera aldatzea, irakaskuntza-metodoak eraberritzea, eta oro har, ikasleak irakaskuntza-sistemaren ardatz bilakatzea (Campos eta Juaristi, 2008). Etorkizuneko gizarteak, ikasle graduatuek oinarrizko ezagutza batzuk izateaz gain, arazoak ebazteko, analizatzeko, sintetizatzeko, aurkezteko eta ebaluatzeko gaitasuna izatea ere esperoko du (Dochy, Segers, Van den Bossche eta Struyven, 2005). 
Horrekin guztiarekin bat eginez, Euskal Herriko Unibertsitateak Ikaskuntza Kooperatibo eta Dinamikoa (IKD) bultzatzeko, irakasleen funtzio berrien eta ikaskuntza-irakaskuntza metodologia berrien inguruko informazioa hedatzeko hainbat jardunaldi eta ikastaro antolatu ditu. Esaterako, unibertsitateko Hezkuntzarako Laguntza Zerbitzuak, irakasleak irakaskuntza-metodologia aktiboetan trebatzeko, ERAGIN izeneko programa bat antolatzen du, eta, berau martxan jartzeko eta irakasleak trebatu ahal izateko, urtero, deialdi berri bat ateratzen du. Programa honen eta antzekoen helburu nagusia da irakasleak metodologia aktiboetan trebatzea eta aditu bilakatzea, alde batetik, pixkanaka eurak irakasten dituzten irakasgaiak eraberritzen joan daitezen, eta bestetik, beste irakasleekin koordina daitezen eta hauei ere metodologia aktibo horiek martxan jartzen irakats diezaieten.

ERAGIN programaren barruan eskaintzen den metodologia aktiboetako bat Problemetan Oinarritutako Ikaskuntza (POI) da. POI ondo definitutako problema zehatz baten ebazpenean oinarritzen da, eta, funtsean, ikasleei teoria eta praktika uztartzen dituen ikaskuntza eskaintzea du helburu. Hasierako definizioetako baten arabera, POI problema baten ebazpena ulertzeko prozesuan zehar lortutako ikaskuntza bezala definituko litzateke, eta bi helburu pedagogiko nagusi izango lituzke: problemarekin lotutako ezagutza integratua eskuratzea, eta problemen ebazpenerako teknikak garatzea eta aplikatzea (Barrows eta Tamblyn, 1980). Ia hogei urte beranduago, Rhemek (1998) POI taldeko lanaren bidez ikasleek testuinguru batean planteaturiko problema bati aurre egiteko estrategia pedagogiko bezala definitu zuen. Ildo horretatik, POI esperientzian oinarritutako ikaskuntza metodologia litzateke, bideratua eta mundu errealeko arazoak ikertzeko eta konpontzeko helburuarekin antolatuta dagoena (Torp eta Sage, 2002). Beste autore batzuek, aldiz, definizioan ikasleek lor ditzaketen ezaugarriei gerturatzea proposatzen dute. Horrela, POI egunerokotasuneko problemak erabiltzera bultzatzen duen hezkuntza profesional bezala ulertzen da, berauen inguruan eztabaidatzera bultzatzen duena eta, aldi berean, ikaskuntza konstruktibo eta esanguratsua eskaintzen dituena (Berkel eta Schmidt, 2000). Hmelo-Silverek (2004) POI metodo instrukzional bezala deskribatzen du, eta problema konplexu baten aurrean erantzun bat baino gehiago izan dezakeen ebazpen-prozesuan oinarritzen dela dio. Ildo beretik, definizio eguneratuago baten arabera, POI ikaslean zentraturiko metodo instrukzionala da, zeinaren bidez problemak aztertzeko, sintetizatzeko eta ebaluatzeko gaitasunak hobetzen diren (Ramsay eta Sorrell, 2007).

Esan daiteke POIren sustraiak unibertsitatearen eremuan kokatzen direla. Jatorriaren inguruan eztabaida dagoen arren, badirudi metodologia hau 1960. eta 1970. urteen bitartean garatu zela Kanadako mediku eskoletan, betiko ikaskuntzari aukera desberdin bat emango zion bide berritzaile gisa (Barrows eta Tamblyn, 1980; Birch, 1986; Loyens, Magda eta 
Rikers, 2008; Whitehill, Bridges eta Chan, 2014). Sorreran, abiapuntua, ikasleek egunerokotasunean oinarritutako ezagutza praktikoa hobetzea zen. Helburu horrekin planteatu zen ikaslearengan zentraturiko ikaskuntza mota hau, non ikaskideekin batera lan eginez, problemak ebazteko irtenbideak aurkitzera bultzatzen zitzaien. Pixkanaka, estrategia edo metodologia hau, osasun zientzietako beste ikasketetan ere ezartzen hasi zen (erizaintzan, odontologian, terapia okupazionalean, eta psikologia klinikoan, besteak beste) eta, ondoren, programa profesionaletara, ingeniaritzara, arkitekturara eta hezkuntza bezalako ikasketetara hedatu zen (Whitehill et al., 2014). Egun, oinarrizko eta bigarren hezkuntzan ere erabiltzen da (Torp eta Sage, 2002).

POIren bereizgarriei dagokienez, esan daiteke ezaugarri ezberdinak identifikatu izan direla autore ezberdinen arabera. Dolmans, De Grave, Wolfhagen eta Van der Vleuten autoreek (2005), adibidez, lau ezaugarri azpimarratu dituzte; beraien aburuz, ikaskuntzak konstruktiboa, norberak zuzendua, kolaboratiboa eta testuinguruko prozesu bat izan behar du. Johnson, Johnson eta Smithen (1998) arabera ere, POIren funtsa ikaskuntza kooperatiboa da, eta honako bost oinarrizko ezaugarri aipatzen dituzte: interdependentzia positiboa, norbere erantzukizuna, zuzeneko elkarrekintza, gaitasun soziala eta talde-lana.

Praktikan, POI metodologia aplikatu ahal izateko, agerikoak, zehatzak eta anbiguetaterik gabeak diren ikaskuntza-helburuak eta problema bat (egoera arazotsu bat, kasu bat...) eduki behar ditugu. Hau da, ikasleak egoera baten aurrean kokatu behar ditugu eta egoera hau baliagarriagoa izango da ikasleek identifika ditzaketen elementuak dituen heinean eta lan mundua islatzen duen heinean (Branda, 2009). Horretaz gain, garrantzitsua da problema ikasleek ikaskuntza-esparruak identifikatzea estimulatzen duen moduan idatzia egotea. Behin abiapuntua ezarri ostean, ikasgelan egingo den lanak hainbat pauso edo etapa jarraitu beharko ditu. Brandari (2013) jarraituz, hauek dira etapa nagusiak:

- Ideien ekaitza eta ikaskuntza-plana: problemaren planteamenduaren ostean, ikasleek ikaskuntza-esparruak identifikatzen dituzte, eta ikaskuntza-plana ezartzen dute, helburuekin edo/eta lan-hipotesiekin. Etapa honek helburu horiek lortzeko beharrezkoak diren informazio-iturriak aukeratzera bultzatzen ditu ikasleak.

- Problemaren edo egoeraren jarraipena: ikasle bakoitzak erabilitako iturrien inguruko informazioa ekartzen du taldera, eta bertan ikuspuntu kritiko batekin, iturrien inguruko eztabaida egiten da. Problema berriz ebaluatzen da, eta ikaskuntza-plana eta planteatutako hipotesiak berrikusten dira. Norberak, modu autonomoan, lortutako informazioa modu aktiboan eta estimulatzailean aplikatzen dio problemari; horrela, informazioa ikaslearen ezagutzan barneratzen da, eta aurrerago beste problema eta egoeretan aplika dezake. 
- Ezagutzaren laburpena eta abstrakzioa: prozesua amaitutakoan, ikasleek, ikaskuntza-helburuak kontuan izanda, zer ikasi duten identifikatu behar dute. Lortutako ikaskuntzak identifikatzea bezain garrantzitsua da ezagutza berri hori etorkizunean nola eta zein esparrutan aplika daitekeen ulertzea. Azkenik, nabarmendu diren baina aztertu ez diren gaiak edo ezagutza-esparruak identifikatu behar dira. Horiek etorkizuneko ikaskuntza-helburuak izan daitezke.

POIren ikaskuntza-irakaskuntza prozesuan oinarrizkoak bezala kalifikatu ditzakegun etapa hauek, hainbat pauso edo aktibitate espezifikoetan zehaztuko lirateke. Aktibitate hauek, landu nahi den problemaren (edo problemaren zatiaren) arabera, hainbat saiotan zehar emango lirateke. Interesa duen irakurleak talde handietan egiteko egokitutako pauso hauen adibide bat ikus dezake, lehen aipatutako Brandaren (2013) lanean. Horretaz gain, hemen aurkezten den irakasgairako diseinatu ziren saioen kronograma eta pausoen sekuentzia ere kontsulta daitezke irakasle-taldearen aurreko argitalpen batean (Vozmediano, Lertxundi, Gorostiaga, Vergara eta Isasi, 2012).

Azkeneko urteotan metodologia aktiboen erabilpena arlo eta irakasgai ezberdinetara hedatu da eta, bere eraginkortasunaren inguruan azterketa ugari egin diren arren, emaitza guztiak ez datoz bat eta, ondorioz, oraindik zalantzak daude bere egokitasunaren inguruan. POI metodologia erabili duten hainbat irakaslek esperientzia hori ebaluatu egin dute, bere eraginkortasuna aztertu ahal izateko. POIren eraginkortasunaren inguruan egindako ikerketa gehienek bere aldeko emaitzak lortu dituztela esan daiteke. Ikerketetako askok, metodologia tradizionala eta POI metodologia alderatu dituzte, eta azken honen bidez lortutako emaitzak hobeak izan direla ikusi dute (Díaz-Véliz et al., 2011; Vidic, 2010). Metodologia honek ikasleei eskaintzen dizkien onurak modu sakonagoan aztertzean, autore ezberdinek arrazoi eta mekanismo ezberdinak azpimarratu dituzte. Birchen (1986) arabera metodologia honek ikasleen pentsaera bere osotasunean garatzea bultzatzen du, teoria eta praktika modu naturalean uztartzen dituen heinean. Harlandek (2002) POI metodologiak ikasleei ikuspuntu propioak eta autonomia lantzen laguntzen diela dio, eta horrela, epe luzerako gaitasunak ikasten dituztela. Ildo beretik, Saveryk (2006) ikasleek goi mailako pentsamendu-gaitasunak eta norberak erregulatutako ikaskuntzaohiturak hartzen dituela azpimarratzen du. Bestalde, Kumar eta Natarajanek (2007) ikasleen eztabaidarako eta taldean lan egiteko beharrezkoak diren komunikazio sozialerako gaitasunen garapena gailentzen dute eta baita honek eragiten duen hazkuntza kognitibo eta intelektuala ere. Koh, Khoo, Wong eta Koh autoreek (2008) aurrekoekin bat egiten dute eta POI metodologiak ikaskuntzarekin erlazionatutako konpetentzietan dituzten eragin positiboak azpimarratzen dituzte, bereziki dimentsio sozial eta kognitiboan. 
POI metodologiaren eraginkortasunaren azterketaz gain, hainbat kasutan, metodologia aktibo honi buruz ikasleek duten pertzepzioa ere neurtu izan da. Ikerketa horiek diotenez, oro har, ikasleek POI metodologiari buruzko pertzepzio positiboa dute (Azman eta Shin, 2012; Cantürk-Günhan, Bukova-Güzel eta Özgür, 2012). Horren harira, Hussain, Mamat, Salleh, Saat eta Harlandek (2007) ikasleek metodologia honi buruz zuten pertzepzioa aztertzean, ikasleek euren deskribapenetan gehien erabili zituzten adjektiboak dibertigarria, motibagarria, erosoa, kitzikagarria eta esanguratsua izan zirela ikusi zuten.

Horretaz gain, metodologia honek ikasleen motibazioa, informazioa prozesatzeko gaitasuna eta euren arteko kolaborazioa nabarmen hobetzen ditu (Latasa, Lozano eta Ocerinjauregi, 2012); eta komunikazio-gaitasunak eta ezagutzaren ulermena hobetzen ditu, eta ezagutza teorikoa praktikan ipintzea errazten du (Bin Yuan et al., 2011).

Hori guztia kontuan izanik, artikulu honek bi helburu nagusi ditu. Alde batetik Psikologia Graduko bigarren mailako «Datuen Analisia eta Diseinuak: Metodo ez Esperimentala» irakasgaian, Problemetan Oinarritutako Ikaskuntza nola aplikatzen den deskribatzea, eta, bestetik, 2013-2014 ikasturtean irakasgai honetan lortutako emaitzak aztertzea.

\section{METODOLOGIA}

\section{Lagina}

Ikerketa honetan parte hartu zuen lagina Euskal Herriko Unibertsitateko Psikologia Graduko 2013-2014 ikasturteko ikasleek osatu zuten. Zehazkiago, graduko bigarren mailako lehenengo lauhilekoan «Datuen Analisia eta Diseinua: Metodo ez esperimentala» irakasgaia egin zuten euskarazko nahiz gaztelaniako ikasleak izan ziren parte hartzaileak. Ikasturte horretan guztira 242 ikasle matrikulatu ziren irakasgaian, eta horietatik 220 (51 mutil eta 169 neska) aurkeztu ziren azterketara, lehen edo bigarren deialdian.

\section{Irakasgaian zehar erabilitako Problemaren eta Metodologiaren deskribapena}

Erabilitako metodologia aktibo honekin ikasleek «Datuen Analisia eta Diseinuak: Metodo ez Esperimentala» irakasgaiarekin lotutako sei gaitasun zehatz lortzea da helburua. Lortu nahi diren gaitasunak hauek dira:

1. Estatistika inferentzialeko hipotesi-froga eta analisi nagusiak eta diseinu ez-esperimental nagusiak ezagutzea. 
2. Ikerketa ez-esperimentalak planifikatzeko gai izatea, baliotasunaren aurkako mehatxuak kontuan hartuz eta estrategia analitiko egokiak erabiliz.

3. Datuak jasotzeko, hipotesiak eraikitzeko eta egiaztatzeko, eta oinarrizko ikerketak diseinatzeko gai izatea, ikerketaren arau etikoak kontuan hartuz.

4. Diseinu ez-esperimental batetik abiatuz, jasotako datuak aztertzeko gai izatea tresna estatistikoak edota informatikoak erabiliz.

5. Ikerketako artikuluak modu kritikoan aztertzeko eta lortutako ondorioak besteen aurrean aurkezteko eta defendatzeko gai izatea.

6. Informazio- eta komunikazio-teknologiak modu egokian erabiltzeko eta irakasgaiaren edukiei aplikatzeko gai izatea.

Esan bezala, aipatutako gaitasun horiek lantzeko asmoz, Problemetan Oinarritutako Ikaskuntza metodologia erabili da. Gure kasuan, metodologia hau ikasleek bakarka edo talde txikietan landu beharreko problema edo arazo orokor batean oinarritzen da. Zehazkiago, ikasleek irakasgaian zehar ikasten dutena hasieran planteatzen den problema bat ebazteko erabili behar dute, eta, horretan ari direla, aurkitzen dituzten oztopoak gainditzen saiatu behar dira, euren kabuz edo taldeka, informazioa bilatuz eta teorian ikasitakoa aplikatuz. Jarraian irakasgai honetan planteatzen den problema azaltzen da, modu laburrean:

«Psikologian graduatu berria zara eta gizarte-gaien inguruko ikerketa interesatzen zaizu. Izan ere, gizartean eragina izango duten eta herritarren bizimodua hobetu dezaketen ikerketak egin nahi dituzu. Zure helburua Gizarte eta Osasun Zientzien arloko puntako ikerketa-zentro batean ikertzaile laguntzaile izatea da. CIReSSH (Centre for Innovative Research in Social Sciences and Health) deritzon ikerketa-zentroak bizi-kalitatearen inguruko ikerketak egiten ditu, metodo ez-esperimentala erabiliz. Zentroak bere Donostiako egoitzan hiru hilabeteko praktikak egiteko aukera ematen du, eta praktika horiek hautapen-prozesu gisa ere erabiltzen dira.

Praktiketan dauden ikertzaileak taldetan antolatuko dira eta hainbat ikerketa-zeregin gauzatuko dituzte zentrorako. Praktikak eta hautapenprozesua ikertzaile nagusiak gainbegiratuko ditu.

Praktika hauen helburuetariko bat CIReSSHek proposatutako gai baten inguruko ikerketa-proiektua diseinatzea, idaztea eta aurkeztea izango da. Proiektuetatik hoberena deialdi batera aurkeztuko da Eusko Jaurlaritzaren diru-laguntza eskatzeko. Ikertzaile nagusiaren ustez, ikerketalaguntzaileek autonomoak izan behar dute literaturaren berrikuspenak egiteko eta proiektu sinpleak diseinatzeko, esperientzia gehiago duen ikertzaile baten laguntzarekin. Ondorioz, praktiketako hiru hilabeteetan 


\begin{abstract}
Psikologiako onlineko datu-baseak erabiliz literaturaren berrikuspena egin, aurrekariak eta erreferentzia bibliografikoak idatzi, ikerketaren helburu eta hipotesiak zehaztu, eta ikerketa diseinatuko duzue, zati hauek guztiak ikerketa-proiektu koherente eta garrantzitsu batean idatziz, APA formatua jarraituz. Proiektua diseinatzeko prozesuan ikerketaren alderdi etikoak kontuan hartu beharko dituzue zuen lana etikoki egokitzat hartua izan dadin. Azkenik, zuen proiektua aurkeztuko duzue ikaskideen aurrean. Proiektua kalitatezkoa bada eta deialdian arrakasta izateko irizpideak betetzen baditu, Gizarte eta Osasun Zientzietan ezagutza berriak lortzeko aukera emango du.»
\end{abstract}

Irakasgai honen testuinguruan eraiki dugun problemak dituen ezaugarri nagusiak hauek lirateke: ikasleari problemaren kasu bakoitzak, edo azpiproblema bakoitzak, zein helbururi erantzuten dion azaltzen zaio, hau da, arazo hori ebaztearekin zer ikasten den argi eta garbi esaten zaio; kasuak gai orokor baten barruan, istorio baten barruan ematen zaizkie, ildo nagusi bati jarraituz (CIReSSH zentroko ikerketa praktikak); ebatzi beharreko arazoak praktika errealean ebatzi beharrekoen oso antzekoak dira (gai konkretu baten inguruko literatura zientifikoaren berrikusketa, beka bat eskatzeko proiektu bat idaztea, datu batzuekin analisi estatistiko batzuk egin eta txosten bat idaztea...); eta azkenik, «ikaslearen koadernoa» izenekoa ematen zaie ikasleei; bertan, arazoa, honen helburuak, testuingurua, garrantzia, teorian ikasten denarekin duen lotura, azalpen gehigarriak... agertzen dira, ikasleek uneoro egiten denari buruzko informazio guztia izan dezaten eta euren kabuz, talde txikietan modu autonomoan lan egiteko aukera izan dezaten.

Erabili den metodologia honen baitan ikasleek egin behar dituzten aktibitate gehienak 6-8 pertsonako taldeetan egin beharrekoak dira. Psikologiako graduan ordu teorikoez gain modalitate ezberdinak daude, hala nola, tailerrak, mintegiak, ordenagailu-praktikak eta gelako praktikak. Modalitate hauetan ikasgela talde txikiagoetan banatzen da eta, beraz, irakasleak ikasle gutxiagorekin lan egin dezake, eta bakoitzari atentzio pertsonalizatuagoa eman diezaioke. Horrela, tailerretan eta gelako praktiketan 3540 ikasle ingururekin lan egiten da, eta mintegietan eta ordenagailu-praktiketan, aldiz, 20-25 ikaslerekin.

Irakasgai honetan Problemetan Oinarritutako Ikaskuntza metodologia erabili ahal izateko hainbat aktibitate ezberdin sortu dira. Egin beharreko aktibitate horiek hiru modalitatetan banatu dira: 1) talde txikietan ikerketa-proiektu bat garatzea eta defendatzea, horretarako klase orduetako tailerrak eta mintegiak erabiliz. Jarduera honekin ikaslea deialdi ofizialetarako ikerketa-proiektuak egiteko trebatu nahi da, eta horretarako dagozkion formatu eta irizpideei jarraitzen ikastea. Ikasgaiaren amaieran ikasle-taldeak ikerketa-proiektua jendaurrean aurkeztu eta defendatu beharko du. Eginkizun honekin, ikasleak estatistika inferentzialeko hipotesi-froga 
eta analisi nagusiak eta diseinu ez-esperimental nagusiak ezagutzea, ikerketa ez-esperimentalak planifikatzeko gai izatea, eta oinarrizko ikerketak diseinatzeko gai izatea lortu nahi da; 2) datuen analisi estatistikoak egiten trebatzeko ordenagailu-praktiketan hainbat analisi estatistiko egingo dira. Jarduera honen xedea Psikologian erabili ohi diren eta diseinu ez-esperimentalei dagozkien oinarrizko analisi-teknika estatistikoak ikasleek ezagutzea eta erabiltzea da. Erabiliko diren lanabesak analisi estatistikoetarako SPSS eta $R$ Commander programa-bildumak izango dira; 3 ) azkenik, testu zientifikoen azterketa lantzeko, gelako praktiketan ikasleek metodo ez-esperimentaleko ikerketaren ezaugarri nagusiak identifikatuko dituzte, ikerketaren helburua, hipotesiak, diseinu mota, aldagaiak, laginketa-teknikak eta abar identifikatuz, eta ikerketaren emaitza eta ondorioak interpretatuz. Lehenengo eta hirugarren modalitateen xehetasunak ezagutzeko, irakasle-taldeak argitaratuta daukan ikaslearen koadernoa kontsulta daiteke (Vozmediano et al., 2012).

\section{Aldagaien operatibizazioa}

POI metodologian parte hartu duten ikasleen kasuan ondoko aldagaiak ebaluatu dira:

Datuen analisi estatistikoak 1. Irakasgaiaren ebaluazioan \% 4ko pisua zuen aktibitatea. Aktibitate honetan ikasleek kontingentzia-taulak egin behar zituzten, interpretatu eta estilo zientifiko egokian idatzi.

- Datuen analisi estatistikoak 2. Irakasgaiaren ebaluazioan \% 4ko pisua zuen aktibitatea. Aktibitate honetan, ikasleei 5 hipotesi zientifiko eman zitzaizkien eta hipotesi horiek frogatzeko analisi egokiak egin behar zituzten, interpretatu eta emaitzak estilo zientifiko egokian idatzi.

- Testu zientifikoen azterketa 1. Irakasgaiaren ebaluazioan \% 5eko pisua zuen aktibitatea. Aktibitate honetan ikasleek inkesta diseinua erabiltzen zuen artikulu zientifiko baten bertsio laburtua irakurri behar zuten eta, ikerketaren alderdi garrantzitsuenak identifikatzeaz gain, korrelazioak eta erregresio analisiak interpretatu.

- Testu zientifikoen azterketa 2. Irakasgaiaren ebaluazioan \% 7ko pisua zuen aktibitatea. Aktibitate honetan ikasleek hainbat analisi ezberdin interpretatu behar zituzten.

- Proiektua.- Irakasgaiaren ebaluazioan \% 10eko pisua zuen aktibitatea. Aktibitate honetan, ikerketa-gai bat proposatzen zitzaien, fikziozko diru-laguntzen deialdi jakin batean ikerketa-proiektu bat aurkez zezaten. 


\section{EMAITZAK}

«Datuen analisia eta diseinuak: Metodo ez esperimentala» irakasgaian, matrikulatu ziren ikasle gehienak $(\% 90,91)$ azterketara aurkeztu ziren. Aurkeztu ez ziren ikasleak 22 izan ziren, eta horietatik 18 ikaslek (\% 75), POI metodologia ez erabiltzea erabaki zuten. Aurkeztu ziren ikasleei dagokienez, 214 ikaslek (\% 97,27), POI metodologia erabiltzea erabaki zuten.

Irakasgaia gainditu eta gainditu ez zuen ikasle kopuruari dagokionez, jarraian agertzen den 1. taulan ikus daitekeen bezala, POI metodologia aukeratu zuten ikasle gehienek, \% 87,9k, irakasgaia gainditu zuten. Metodologia tradizionala aukeratu zuten ikasleak oso gutxi izan ziren, eta kasu honetan erdiak izan ziren irakasgaia gainditu zutenak.

1. taula

Metodologia bakoitzean gainditu zutenen eta ez zutenen maiztasuna

\begin{tabular}{l|cc|cc|c}
\hline & \multicolumn{2}{|c|}{ Gainditua } & \multicolumn{2}{c|}{ Ez gainditua } & \multirow{2}{*}{ Guztira } \\
\cline { 2 - 5 } & $\mathrm{n}$ & $\%$ & $\mathrm{n}$ & $\%$ & \\
\hline POI metodologia & 188 & 87,9 & 26 & 12,1 & 214 \\
Metodologia tradizionala & 3 & 50,0 & 3 & 50,0 & 6 \\
\hline
\end{tabular}

Jarraian agertzen den 2. taulan, POI metodologia aukeratu zuten 214 ikasleek burututako aktibitate bakoitzean lortutako kalifikazioak azaltzen dira. Kalifikazioak 0tik 10erako eskalan daude, 0 kalifikazio baxuena eta 10 kalifikazio altuena delarik. Oro har, hiru modalitateetan ikasleek lortu zituzten kalifikazioak antzekoak direla ikus daiteke eta horrela lortutako batez besteko kalifikazio baxuena $6,47 \mathrm{koa}$ eta altuena, aldiz, 7,94koa izan zen.

2. taula

POI metodologiako aktibitateen batez bestekoa eta desbideratze tipikoa

\begin{tabular}{lcc}
\hline \multicolumn{1}{c}{ Aktibitatea } & $\begin{array}{c}\text { Lortutako batez besteko } \\
\text { kalifikazioa }\end{array}$ & Desbideratze tipikoa \\
\hline Datuen analisi estatistikoak 1 & 6,47 & 2,94 \\
Datuen analisi estatistikoak 2 & 7,94 & 2,12 \\
Testu zientifikoen azterketa 1 & 7,72 & 1,52 \\
Testu zientifikoen azterketa 2 & 6,61 & 2,71 \\
Proiektua & 6,65 & 0,88 \\
\hline
\end{tabular}


3. taula

POI metodologiako aktibitateen arteko Spearmanen korrelazioak

\begin{tabular}{lllllc}
\hline & 1 & 2 & 3 & 4 & 5 \\
\hline 1. Datuen analisi estatistikoak 1 & 1 & $0,64 * *$ & $0,58^{* * *}$ & $0,33^{* *}$ & $0,57^{* *}$ \\
2. Datuen analisi estatistikoak 2 & & 1 & $0,56^{* *}$ & $0,42^{* *}$ & $0,42^{* *}$ \\
3. Testu zientifikoen azterketa 1 & & & 1 & $0,31^{* *}$ & $0,49^{* *}$ \\
4. Testu zientifikoen azterketa 2 & & & & 1 & $0,23^{* *}$ \\
5. Proiektua & & & & & 1 \\
\hline
\end{tabular}

Oharra: $* * p<0,01$.

POI metodologiaren baitan burututako aktibitateetan lortutako kalifikazioen arteko erlazioak 3. taulan agertzen dira. Bertan, korrelazio guztiak positiboak eta estatistikoki esanguratsuak direla ikus daiteke. Horrela, erlazio altuena Datuen analisi estatistikoak 1 eta 2 aktibitateen artean ematen da $(r=0,64)$, eta «Datuen analisi estatistikoak 1 » eta Testu zientifikoen azterketa 1 eta Proiektua aktibitateen artean ere $(r=0,58$, eta $r=0,57$, hurrenez hurren), eta Datuen analisi estatistikoak 2 eta Testu zientifikoen azterketa 1 aktibitateen artean $(r=0,56)$ ere erlazio altuak ematen dira. Horiez gain, Datuen analisi estatistikoak 2 eta Testu zientifikoen azterketa 2 eta Proiektua aktibitateen artean $(r=0,42$, bi kasuetan) eta Testu zientifikoen azterketa 1 eta Proiektua aktibitateen artean $(r=0,49)$ erlazio moderatuak agertzen dira.

\section{ONDORIOAK}

Azken urteotan gizartea maila ezberdinetan eraldatzen ari da, eta, horrekin batera, ikaskuntza-prozesua, irakaskuntza-jarduerak, irakasleek, eta baita ikasleek ere, ikasgelan, eta hortik kanpo egiten dutena ere aldatzen ari da. Horren ondorio bezala, metodologia eta dinamika berriak, problemetan oinarritutako ikaskuntza, kasu praktikoak, gelako eztabaida-dinamikak, ikaskuntza kooperatiboa... gero eta gehiago erabiltzen dira, eta hauek ikasleen ikaskuntza-prozesuan zein eragin izan dezaketen aztertzeak garrantzia hartu du. Alor ezberdinetan egiten diren esperientziak ebaluatuz eta emaitzak plazaratuz, honen inguruko jakintza maila handiagotuko da, eta horrek irakasle-talde bakoitzari bere esparrutik, dagokion irakasgaia modu egokiagoan planteatzea ahalbideratuko dio.

Irakasgaia diseinatu duen eta POI bidez berau aurrera eraman duen taldeak egindako hausnarketa moduan, esan dezakegu ados gaudela González eta kolaboratzaileek (2015) esaten dutenarekin, hau da, metodologia berri honekin lan egiteak irakaskuntza-taldeari berari ere zenbaitetan zailtasunak eragin dizkiola. Metodologia honetan irakasleek eman behar duten gi- 
daritza eta laguntza handiagoa da, batez ere klase magistraletara ohituta dauden ikasleek laguntza asko eska baitezakete ikasteko modu berri honetarako eraldaketan. Hori horrela izanik ere, ados gaude esfortzu gehigarri horrek merezi duela esaten dutenean ere, modu honetan emandako edukiaren ulermen sakonagoa ematen baita. Uste dugu gure ikasgelan burutu den lanak, Brandak (2009) aipatzen dituen POI bidezko ikaskuntzaren hiru printzipioak berrestea ahalbideratzen duela, hala nola: 1) Ikaskuntza ez dela jasotzera mugatzen den prozesu bat, baizik eta, oroimenaren ezaugarri garrantzitsuenetako bat bere egitura asoziatiboa denez, ikaskuntza-prozesu eraikitzailea dela; 2) Metakognizioak ikaskuntzan eragina duela. Norberaren ezagutzari buruzko hausnarketak ikaslea modu zuzenean bere ikaskuntzaz arduratzea eragiten du; eta 3) Ezaugarri sozialek eta testuingurukoek eragina dute irakaskuntzan. Gure irakasgaian, berau ikerkuntza-metodologia arlokoa izanik eta batzuetan ikasleei abstraktua edo zaila iruditzen zaien irakasgaia izanik, problema baten bidezko ezagutzaren eraikitze kolektiboak eta aktiboak, gure ustez, aurreko ezagutzei lotutako inplikazio maila handiagoa duen ikaskuntza eraikitzaile hori gauzatzeko aukera ematen du.

Lortutako emaitzek hausnarketa horiei oinarri enpirikoa ematen dietela uste dugu. Horrela, adibidez, metodologia mota hau erabiltzea hautatu zuen ikasle-portzentajeari, eta irakasgaia gainditu zutenen portzentajeari erreparatuz gero, bi hausnarketa egin ditzakegu. Lehenik eta behin, azterketara aurkeztu ez ziren ikasle gehienek metodologia tradizionala aukeratu zutela. Horrek zera esan nahi du, POI metodologia hautatzen dutenak azterketara aurkezteko joera handiagoa dutela, eta hori, oso interesgarria dela uste dugu, batez ere, ikasleek zailak bezala hautematen dituzten irakasgaietan. Bigarrenik, POI metodologia hautatu zuten ikasleen gehiengo nabarmen batek irakasgaia gainditu zuela, eta metodologia tradizionalaren kasuan, aldiz, ikasleen erdiak ez zuela irakasgaia gainditu. Horrek POI metodologiarekin ikasleek edukiak hobeto barneratzen dituztela pentsarazi diezaguke. Emaitza hau bat dator metodologia tradizionala eta POI metodologia alderatu, eta POI metodologiaren bidez emaitza hobeak lortzen direla dioten autoreekin (Díaz-Véliz et al., 2011; Vidic, 2010).

Ikasleen gehiengo nabarmenak POI metodologia hautatu zuela ikusita, badirudi irakasgaia egiteko modu hau hobetsi zutela. Hori bat dator ikasleek Problemetan Oinarritutako Ikaskuntzari buruzko pertzepzio positiboa dutela ondorioztatu duten ikerketekin (Azman eta Shin, 2012; CantürkGünhan, Bukova-Güzel eta Özgür, 2012; Hussain, Mamat, Salleh, Saat eta Harlandek, 2007).

Bestetik, Problemetan Oinarritutako Ikaskuntzaren aplikazioari dagokionez, kasu honetan metodologia honen barnean eraikitako problemak edo praktika desberdinak elkarren arteko koherentzia izan dutela ere ondoriozta dezakegu. Horrela, esan dezakegu praktika desberdinak eta proiektua elkarrekin erlazionatuta zeudela. Hau da, kasu batzuetan lortutako ezagutza besteetan aplikatzen zutela. 
Azkenik, ikasleen pertzepzioa etorkizunean sakonean aztertu beharko litzatekeen gaia dela aipatu nahiko genuke. Ikerketa honetan ikasleek POI metodologia hobetsi zutela argi geratu da, baina etorkizunean horren zergatia modu sakonagoan aztertzea interesgarria litzateke. Horren ildotik, problemak eraginkorrak izateko bete behar dituzten baldintzetako bat koherentzia eta errealismoa direnez (Azer, Peterson, Guerrero, eta Edgren, 2012), ikasleek, planteatutako problemak nola hauteman dituzten aztertzea ere garrantzitsua litzatekeela uste dugu. Gure ikerketaren mugetako bat metodologia bat edo beste zergatik aukeratu den ez aztertzea izan da; etorkizunean metodologiaren inguruan ikasleek duten iritzia jasotzea interesgarria litzateke, berau hobetzeko moduen inguruan ere galdetuz, horrela, metodologia bera hobetzen joan ahal izateko. Horretaz gain, ikasleen ustez metodologia honekin zehazki zein gaitasun lortu dituzten jakiteak benetako ebaluazio integrala egitea ahalbideratuko ligukeela deritzogu.

The University of the Basque Country want to encourage the Cooperative and Dynamic Learning, and to do so, among other measures, has developed the ERAGIN program. One of the active methodologies that is trained in this program is the Problem Based Learning (PBL) methodology. Thus, the present article has two main objectives: to describe the application of PBL methodology in the course «Data analysis and Designs: Non-Experimental Method» which is offered on second grade of Psychology Degree in the University of the Basque Country, and to analyze the results obtained. The sample consisted in 242 students matriculated in the course. In order to achieve the course's competencies, in the PBL context students worked in a problem either individually or collectively. In relation to the results, from the students who selected PBL methodology, the majority (87,9\%) passed the course. Furthermore, the correlations among the grades obtained in the different activities were positives and statistically significant. In the future, in order to better analyze the effectiveness of $A B P$ methodology in a comprehensive way, it will be useful to assess the perception that students have about the methodology besides their academic grades.

Key words: Active learning; Problem Based Learning; Higher education; Data analysis 
La Universidad del País vasco pretende impulsar el Aprendizaje Cooperativo y Dinámico,y para ello, entre otras medidas, ha desarrollado el programa ERAGIN. Una de las metodologías activas que se trabaja en este programa es el Aprendizaje basado en Problemas $(A B P)$. Así, este artículo tiene dos objetivos principales: describir la aplicación de la metodología ABP en la asignatura "Análisis de Datos y Diseños: Método no Experimental» de segundo curso del Grado de Psicología de la Universidad del País Vasco y, analizar los resultados obtenidos. La muestra estuvo compuesta por 242 estudiantes matriculados/as en la asignatura. Con el fin de adquirir las competencias de la asignatura, en el contexto ABP, el alumnado trabajó sobre un problema individualmente o en pequeños grupos. En relación a los resultados, de los/as estudiantes que optaron por la metodología ABP, la mayoría (87,9\%) superó la asignatura. Además, las correlaciones entre las calificaciones de las actividades propuestas desde dicha metodología fueron positivas y estadísticamente significativas. En el futuro, para poder analizar la efectividad del ABP de forma integral, se observa la necesidad de evaluar, además de los resultados de los alumnos/as, la percepción del alumnado sobre dicha metodología.

Palabras clave: Aprendizaje activo; Aprendizaje Basado en Problemas; Enseñanza superior; Análisis de datos.

L'Université du Pays Basque souhaite impulser l'apprentissage coopératif et dynamique et pour se faire a développé le programme ERAGIN. Une des méthodes qui est travaillée dans ce programme concerne l'apprentissage par problème $(A B P)$. Ainsi, cet article a pour principal objectif de découvrir l'application de la méthodologie $A B P$ au niveau de la matière "Analyse de données et dessins: méthodes de recherche non expérimentales » du deuxième cours de la branche Psychologie de l'Université du Pays Basque et analyse des résultats obtenus. L'échantillon était composé de 242 étudiant(e)s inscrit(tes) au cours. Afin d'acquérir les compétences sur cette matière, dans le contexte de l'ABP, l'élève travaillait sur un problème individuellement ou en petit groupe. En relation aux résultats des étudiants que ont choisit la méthode $A B P$, la majorité $(87,9 \%)$ a réussit les examens de cette matière. De plus, le lien entre qualification et activités proposées basées sur cette méthode a été positive et statistiquement significatif. A partir de maintenant, pour pouvoir analyser l'efficacité de l'ABP de manière complète, il est nécessaire d'évaluer en plus des résultats des étudiants, la perception de l'étudiant sur la méthodologie.

Mots-clé: Apprentissage par l'action; Apprentissage par problème; Enseignement supérieur; Analyse de données 


\section{ERREFERENTZIAK}

Azer, S. A., Peterson, R., Guerrero, A. P. S. eta Edgren, G. (2012). Twelve tips for constructing problem-based learning cases. Medical Teacher, 34(5), 361-367.

Azman, N. eta Shin, L. K. (2012). Problem-based learning in English for a second language classroom: Students' perspectives. International Journal of Learning, 18(6), 109-126.

Barrows, H. S. eta Tamblyn, R. M. (1980). Problem-Based Learning: An approach to medical education. Nueva York: Springer Publishing Co.

Berkel, H. J. M. V. eta Schmidt, H. G. (2000). Motivation to commit oneself as a determinant of achievement in problem-based learning. Higher Education, 40(2), 231-242.

Bin Yuan, H., Williams, B., Yin, L., Liu, M., Bo Fang, J. eta Pang, D. (2011). Nursing students' views on the effectiveness of problem-based learning. Nurse Education Today, 31, 577-581.

Birch, W . (1986). Towards a model for problem-based learning. Studies in Higher Education, 11(1), 73-82.

Branda, L.A. (2009). El aprendizaje basado en problemas. De herejía artificial a res popularis. Educación Médica, 12, 11-23.

Branda, L.A. (2013). El abc del ABP, lo esencial del aprendizaje basado en problemas. Quaderns de la Fundació Dr. Antoni Esteve, 27, 1-16.

Campos, T. eta Juaristi, P. (2008). Goi-mailako Hezkuntzaren Europako Esparrua: aurrerapausuak eta erronkak. Jakin, 168, 11-22.

Cantürk-Günhan, B., Bukova-Güzel, E. eta Özgür, Z. (2012). The prospective mathematics teachers' thought processes and views about using problem-based learning in statistics education. International Journal of Mathematical Education in Science and Technology, 43(2), 145-165.

Díaz-Véliz, G., Mora, S., Bianchi, R., Gargiulo, P. A., Terán, C., Gorena, D., Lafuente-Sánchez, J. V. eta Escanero-Marcen, J. F. (2011). Percepción de los estudiantes de medicina del ambiente educativo en una facultad con currículo tradicional (UCH-Chile) y otra con currículo basado en problemas (UNC-Argentina). Educación Médica, 14(1), 27-34.

Dochy, F., Segers, M., Van Den Bossche, P. eta Struyven, K. (2005). Students' perceptions of a problem-based learning environment. Learning Environments Research, 8, 41-66.

Dolmans, D. H. J. M., De Grave, W., Wolfhagen, I. H. A. P. eta Van der Vleuten C. P. M. (2005). Problem-based learning: future challenges for educational practice and research. Medical Education, 39, 732-741.

González, P., Ruíz, B., Martiañez, N.L., García, M., Navas, B., Díaz-Meco, R., ... Cañadas, P. (2015). Aprendiendo a aprender. reflexiones de los profesores sobre el ABP. XII Jornadas Internacionales de Innovación Universitaria jardulnaldietan aurkeztutako lana. Villaviciosa de Odón, 2015eko uztailaren 20tik $21 \mathrm{era}$.

Harland, T. (2002). Zoology students' experiences of collaborative enquiry in problem-based learning. Teaching in Higher Education, 7(1), 3-15.

Hmelo-Silver, C. E. (2004). Problem-based learning: What and how do students learn? Educational Psychology Review, 16(3), 235-266. 
Hussain, R. M. R., Mamat, W. H. W., Salleh, N., Saat, R. M. eta Harland, T. (2007). Problem-based learning in Asian universities. Studies in Higher Education, 32(6), 761-772.

Johnson, D. W., Johnson, R. T., eta Smith, K. A. (1998). Cooperative learning returns to college: What evidence is there that it works? Change, 30(4), 26-35.

Koh, G. C., Khoo, H. E., Wong, M. L. eta Koh, D. (2008). The effects of problembased learning during medical school on physician competency: A systematic review. Canadian Medical Association Journal, 178(1), 34-41.

Kumar, M. eta Natarajan, U. (2007). A problem-based learning model: Showcasing an educational paradigm shift. Curriculum Journal, 18(1), 89-102.

Latasa, I., Lozano, P. eta Ocerinjauregi, N. (2012). Aprendizaje basado en problemas en currículos tradicionales: Beneficios e inconvenientes. Formación Universitaria, 5(5), 15-26.

Loyens, S. M. M., Magda, J. eta Rikers, R. M. J. P. (2008). Self-directed learning in problem-based learning and its relationships with self-regulated learning. Educational Psychology Review, 20(4), 411-427.

Ramsay, J. eta Sorrell, E. (2007). Problem-based learning: An adult-educationoriented training approach for SH\&E practitioners. Professional Safety, 52(9), 41-46.

Rhem, J. (1998). Problem-Based Learning: An introduction. The National Teaching \& Learning Forum, 8(1), 1-4.

Savery, J. R. (2006). Overview of problem-based learning: Definitions and distinctions. The Interdisciplinary Journal of Problem-based Learning, 1(1), 9-20.

Torp, L. eta Sage, S. (2002). Problems as possibilities: Problem-based learning for K-16 education (2. Argit.). Alexandria, VA: Association for Supervision and Curriculum Development.

Vidic, A. D. (2010). The Impact of Problem-Based Learning on Statistical Thinking of Engineering and Technical High School Students. Proceedings of the Eight International Conference on Teaching Statistics (ICOTS8). Ljubljana, Eslovenia.

Vozmediano, L., Lertxundi, N., Gorostiaga, A., Vergara, A. I. e Isasi, X. (2012). Cómo llegar a ser el «fichaje estrella» de los equipos de investigación - IKD baliabideak 4- http://cvb.ehu.es/ikd-baliabideak/ik/vozmediano-4-2012-ik. pdf

Whitehill, T. L., Bridges, S. eta Chan, K. (2014). Problem-based learning (PBL) and speech-language pathology: a tutorial. Clinical Linguistics \& Phonetics, $28,5-23$. 